\title{
Analysis of Ability to Pay and Willingness to Pay of Aircraft passengers toward Jakarta Surabaya High-Speed Train
}

\author{
Prasetyaning D.R. Lestari, Djoko P. Utomo, Sucipto, and Asep Y. Nurhidayat
}

\begin{abstract}
The number of aircraft passengers who travel from Jakarta to Surabaya based on data from PT. Angkasa Pura II is increasing rapidly every year within 2012-2017. This amount is much greater when compared with the number of executive train passengers that also increased in the same period of the years. This indicates that passengers tend to choose aircraft as a mode of transport for this route. This could be due to the shorter travel time and comfort offered. However, the high number of aircraft passengers for this route each year can lead to a decrease in airport capacity in serving aviation traffic demand which rapidly increases. This indicates the need for alternative transportation modes to complement the high demand of passengers on the Jakarta-Surabaya route. The Indonesian Government offers the alternative transportation mode that is Jakarta-Surabaya highspeed train to overcome this. Since fare determination for public transport is one crucial matter, it is need to know the ability to pay (ATP) and willingness to pay (WTP) from the passengers. This research will study the ATP and WTP from the aircraft passengers if Jakarta-Surabaya high-speed train will be operated by Indonesian Government. This study compares ATP and WTP to some ticket price intervals of high-speed train. Aircraft passengers' survey has been conducted in airports in Jakarta and Surabaya to gain data of ATP and WTP through interview and questionnaire methods. ATP measurement is using Travel Cost method while WTP using Stated Preference method. As a result, this study offers a range of ticket price deemed to be in line with ATP and WTP of passengers.
\end{abstract}

Index Terms - High-speed train, transportation mode selection, ability to pay, willingness to pay, travel cost, stated preference, ticket pricing.

\section{INTRODUCTION}

Extensive population growth and economic development have caused continuous increases in travel demand and consequently congestion and delays [1]. In order to address

P.D.R. Lestari is with the ${ }^{1}$ Agency for the Assessment and Application of Technology, Serpong, South Tangerang, Banten, Indonesia (e-mail: diah.rizky@bppt.go.id)

D.P. Utomo is with the ${ }^{1}$ Agency for the Assessment and Application of Technology, Serpong, South Tangerang, Banten, Indonesia

Sucipto is with the ${ }^{1}$ Agency for the Assessment and Application of Technology, Serpong, South Tangerang, Banten, Indonesia

A.Y. Nurhidayat is with the ${ }^{1}$ Agency for the Assessment and Application of Technology, Serpong, South Tangerang, Banten, Indonesia growing congestion and delay problems, the Indonesian Government have focused on the capacity expansion of existing transportation infrastructure, such as providing additional capacity of highways, etc. Also, these concerns have motivated the policy makers to acknowledge the needs of a new approach that can address current congestion problems as well as growing travel demand in the future.

One of the most crowded travel route in Java Island is between the two biggest cities, i.e. Jakarta and Surabaya. The most popular transportation mode using by passengers in this route are aircraft and train due to their convenience and faster travel time if compared to other ground fleets (bus, etc.). The number of passengers who travel from Jakarta to Surabaya by aircraft is rapidly increasing every year within 2012-2017. If compared with the number of executive train passengers, this number is much greater in the same period of the years. It means that the passengers tend to choose using aircraft for this trip. It effects on the airport capacity in serving aviation traffic demand. The high load of aviation traffic demand will impact to flight frequency, runway capacity, terminal building capacity and others.

As we know, the Indonesian Government plans to operate the Jakarta-Surabaya high-speed train as an alternative transportation mode option to complement the high demand of passengers on the Jakarta-Surabaya route. The introduction of a new travel mode can affect a mode shift for some travelers and improve travel conditions for other travelers [2]. When a new alternative mode of transportation enters into an existing transportation market, it will inevitably compete with other modes of transportation in the market, and consequently a portion of other mode use will shift to a new mode [1].

There is a growing awareness among transport policy makers that public acceptance and support of new alternative transport-related decisions are essential for the success of such decisions. Long-term policies on the physical conditions, as well as the fiscal, budgetary, and strategic issues of transit systems, are particularly in need of public and user support [3]. In the other hand, fare determination for public transport is also one crucial matter. However, by developing right strategies on fare determination, the Jakarta-Surabaya highspeed train can compete with the aircraft mode competitively.

In Fig. 1.1, the Masterplan of Jakarta-Surabaya high-speed train will be shown as a part of Indonesian Railway Masterplan. 


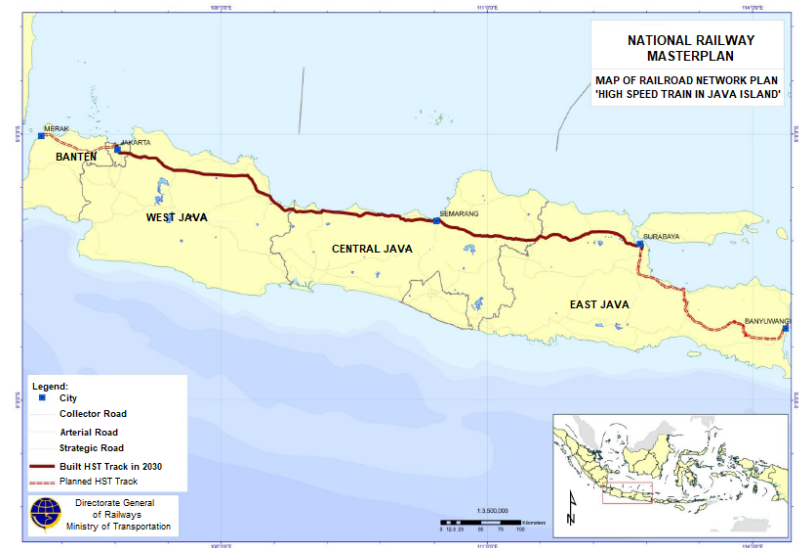

Fig. 1. Jakarta-Surabaya High-Speed Train Track

The figure above shows that there are three main capitals of the Province that will be passed by the high-speed train i.e. Jakarta, Central Java (Semarang) and East Java (Surabaya). It means the demand of Jakarta-Surabaya high-speed train depend on demand of these three areas. In

\section{TABLE I}

Number of Aircraft Passenger for Jakarta-Surabaya, Jakarta- Semarang and Semarang-Surabaya Route there are increased patterns of Jakarta-Surabaya, Jakarta-Semarang and Semarang-Surabaya aircraft passengers from 2012 to 2017 in Soekarno-Hatta International Airport, Juanda International Airport and Ahmad Yani International Airport at annual growth of $4,37 \%, 4,52 \%$ and $9,18 \%$ respectively.

TABLE I

NUMBER OF AIRCRAFT PASSENGER FOR JAKARTA-SURABAYA, JAKARTASEMARANG AND SEMARANG-SURABAYA ROUTE

\begin{tabular}{|c|c|c|c|}
\hline Year & JKT-SBY & JKT-SMG & SMG-SBY \\
\hline 2012 & 4.936 .734 & 2.288 .825 & 227.481 \\
\hline 2013 & 5.613 .642 & 2.056 .839 & 305.389 \\
\hline 2014 & 5.371 .110 & 2.038 .181 & 285.555 \\
\hline 2015 & 5.228 .922 & 2.140 .339 & 302.816 \\
\hline 2016 & 5.860 .098 & 2.425 .269 & 341.948 \\
\hline 2017 & 6.114 .404 & 2.854 .980 & 352.865 \\
\hline $\begin{array}{c}\text { Growth } \\
(\%)\end{array}$ & 4,37 & 4,52 & 9,18 \\
\hline
\end{tabular}

The travel time between Jakarta and Surabaya by using aircraft is about 1,5 hours for on board time [4] and approximately more than 2 hours for airport access/egress and waiting time, while using the fastest existing train, Argo Bromo Anggrek, is about 9 hours [5] only for on board time. The Indonesian Government plans to launch Jakarta-Surabaya high-speed train that will reduce travel time between the two cities become 3-3,5 hours faster than the fastest existing train. When aircraft passengers choose to change their transportation mode into the high-speed train, there will be tight competition between the airlines and high-speed train service companies.

This study was conducted to determine the affordable and desirable cost of Jakarta-Surabaya passengers for high-speed train by collecting data of Ability to Pay (ATP) and Willingness to Pay (WTP) through interview survey and questionnaire methods. They were asked to express their ATP and WTP based on the available services and funds in their household. Their acceptance and the amount of fare increment were also explored in order to express the relationship among fare, ATP and WTP.

This study focus on aircraft passengers' interest in term of ATP and WTP for using Jakarta-Surabaya high-speed train according to variation of travel time. The survey result will be analyzed by comparing some ticket price intervals and then the ideal fare interval basis can be obtained. It should be noted that the limited variables to be considered in this study may cause the model has limitations in representing real conditions in the field.

\section{Literature REVIEW}

\subsection{Ability and Willingness to Pay}

The basic motivation for this study is the question of how users perceive the fare based on their ATP and WTP. Thus, this study explores the ability and the willingness to pay of aircraft passengers who might be the most high-speed train consumer. In economics, the ATP principle means that for a public project, those who are able to afford to pay more should pay more [6]. Meanwhile, the consumer's WTP is the maximum amount that a person would be willing to pay for a service rather than do without it [7].

One of the methods used in analyzing ATP value that used in this study is the Travel Cost Method. This method assumes that the demand for travel to a particular location depends on travel cost, income, travel frequency, etc. The travel costs may vary from location to location depending on distance, where the cost is low for people near the site and the high cost for people living further away [8]. Looking at survey-based techniques for estimation of WTP through interview and questionnaire methods, there exist direct and indirect surveys for collecting the relevant data. Preference data derived from surveys are frequently referred to as Stated Preferences [9].

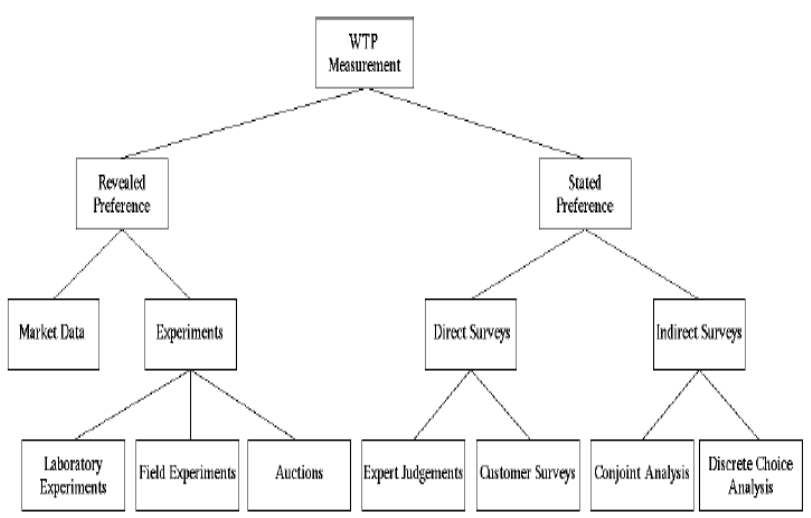

Fig. 2. Classification Framework for Methods to Measure WTP [10]

\subsection{Relationship between ATP and WTP}


In the implementation to determine the tariff of high-speed train, there is often a clash between ATP and WTP. This condition is further illustratively presented in Figure below.

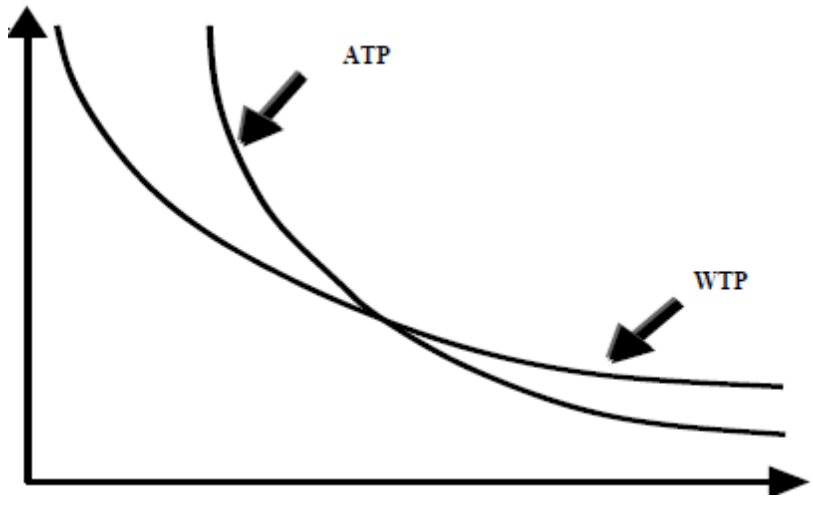

Fig. 3. Curve of ATP and WTP [11]

\section{1) $\mathrm{ATP}>\mathrm{WTP}$}

This condition shows that the ability to pay is greater than the desire to pay for such services. This happens when the user has a relatively high income but the utility for such services is relatively low, the user in this condition is called choice riders.

2) ATP $<$ WTP

This condition is the opposite of the above condition, where the user's desire to pay for the services is greater than his ability to pay. This is possible for users who have relatively low incomes but utilities for these services are very high, so the user's desire to pay for these services tends to be more affected by the utility, in this condition the user is called captive riders.

\section{3) $\mathrm{ATP}=$ WTP}

This condition shows that between the ability and the desire to pay for services is the same. In this condition, there is a balance of users' utility with the cost incurred to pay for these services.

In principle, the determination of tariff can be reviewed from several key aspects of the public transport system. These aspects are:

1) User

2) Operator

3) Regulator (Indonesian Government)

When ATP and WTP parameters are reviewed, in this case, the user aspect is subjected to the determination of the tariff rate applied under the following principles:

1) ATP is a function of the ability to pay, so the tariffs applied, as far as possible does not exceed the ATP value of the target consumer. Government intervention / interference in the form of direct or cross-subsidy is needed under conditions where the tariff is greater than ATP, so the tariff which is equal to the value of ATP can be obtained.

2) WTP is a function of the level of public transport service, so if the WTP value is still below the ATP value, it is still possible to increase the value of tariffs with improved service performance.

\subsection{Competition between High-speed Network and Air Transportation}

In [12], it examined the opportunities for High-speed rail (HSR) in a market dominated by air traffic. The internet data survey among air travelers, showed that HSR will be used more often if connections improve and access times to stations decrease. The first HSR between two European cities, Paris and Lyon, began operations in 1981, [13] report that this HSR connection caused the passenger aviation market share to tumble from 30 to 15 percent. This was a first indication that HSR can compete strongly with air transport in medium distance transport markets.

In Korea the two main airlines providing services between Seoul and the country's other main cities anticipated the arrival of HSR and drastically reduced the frequency of their flights in 2004. For example, between Seoul and Daegu the number of monthly air departures fell from 517 to 293 prior to the entry of HSR and 2 months after the entry they were down to just 183 [14]. These figures are consistent with those of [13].

As for [13] did stated preference techniques to forecast the market share of aviation and HSR after the introduction of the Korea Train Express (KTX) between Seoul and Daegu in 2004. It found that the traffic volume on the air routes servicing the same region as the KTX showed a dramatic drop in demand. Prior to the introduction of this mode of highspeed transport, users were limited to the existing rapid transit means of air transport, but when another transportation option appeared, aviation demand decreased inversely to the increased demand for rail transport. The same situation happened in Taiwan, [15] also found that air services lost market share with the introduction of HSR services.

The pressure of competition and its repercussions seem to mitigate in the long run, especially once the market has adjusted to the entrance of the HSR competitor. [16] consider that the evidence for the large market share gained by HSR Eurostar on the London- Paris route, and the withdrawal of alternative air services, indicates that competition will certainly decline in the long run.

\section{ANALYSIS AND DISCUSSION}

\subsection{Data Collection}

The survey aimed to determine the ATP and WTP of aircraft passengers. The survey was conducted through interview and questionnaire method where passengers were asked by surveyors based on questions on the questionnaire. The payback survey was designed to determine the income and allocation of expenditures for transportation to each respondent. In addition to knowing the willingness to pay, the questionnaire was designed by asking the willingness to pay (done with open questions) on some variations of travel time service conditions offered. Data collection through survey was 
conducted on working days and also holidays. Survey was conducted for at least 16 hours per day or in accordance with the services of the surveyed mode.

Travel time assumed in this study is the travel time of the vehicle in minutes or hours, which is the time required to start the journey from origin station to the destination station (on board). Travel time is then referred to as an attribute which influences transport mode choice behavior. Table 2 shows the attribute scenarios used in this study.

TABLE II

VALUE OF EACH ATTRIBUTE LEVEL

\begin{tabular}{cccc}
\hline \multirow{2}{*}{ Attribute } & \multicolumn{3}{c}{ Value of each attribute scenario } \\
& Scenario 1 & Scenario 2 & Scenario 3 \\
\hline Travel time & 4 hours & 5 hours & 6 hours \\
\hline
\end{tabular}

In this study, we consider only two areas of JakartaSurabaya high-speed train demand, Jakarta as the departing station city and Surabaya as final destination station city. The aircraft passengers' survey has been conducted in airports in Jakarta and Surabaya to gain data of ATP and WTP through interview and questionnaire methods. Jakarta has two international airports, i.e. Soekarno-Hatta International Airport and Halim Perdanakusuma International Airport. While Surabaya has only Juanda International Airport.

In some surveys that involve the collection of sample data, the traffic conditions (passengers) and observed travel behavior (respondents) in a survey location are assumed to provide an overview of general traffic conditions and behavior. Observations made are the result of the total population sampling so as to produce valid data. The selection of respondents in this study refers to the stratified random sampling method in which the process of sampling through the process of dividing the population into strata (location of origin and destination), selects a simple random sample of each stratum and incorporates it into a sample to estimate the population parameter.

Basically there is no single formula that can determine the most appropriate sample size and there are no rules that can explain clearly between large samples and small samples [17]. In this study, Roscoe method is used to determine the number of samples. According to Roscoe, for most studies the sample size of more than 30 and less than 500 is appropriate. In practice, however, the size of the sample targets requires some adjustment depending on the field conditions and the complexity of each survey location. In practice there will be a large diversity of samples collected. In locations with high population the sample ratio is generally low, whereas in locations with low population the sample ratio is generally high. The number of passenger population of the aircraft annually for the surveyed location has been described in

TABLE I

Number of Aircraft Passenger for Jakarta-Surabaya, Jakarta- Semarang and Semarang-Surabaya Route TABLE III

Number of Sample (Total Respondents) in ATP and WTP Survey below shows the number of sample in ATP and WTP survey.
TABLE III

NUMBER OF SAMPLE (TOTAL RESPONDENTS) IN ATP AND WTP SURVEY

\begin{tabular}{ccc}
$\begin{array}{c}\text { Soekarno } \\
\text { Hatta } \\
\text { International } \\
\text { Airport }\end{array}$ & $\begin{array}{c}\text { Halim } \\
\text { Perdanakusuma } \\
\text { International } \\
\text { Airport }\end{array}$ & $\begin{array}{c}\text { Juanda } \\
\text { International } \\
\text { Airport }\end{array}$ \\
\hline 438 & 519 & 485 \\
\hline
\end{tabular}

\subsection{Methodology}

ATP measurement is using Travel Cost method while WTP using Stated Preference method. The respondents ATP data obtained from the questionnaire are inserted into the table, then the data are analyzed and displayed in the form of respondents ATP diagrams that describe the frequency, frequency percentage and the cumulative frequency percentage of the respondent ATP value at certain cost intervals. The ATP of respondents are calculated by the following formula.

$$
A T P=\frac{I C \times \% T C}{D}
$$

Where:

$$
\begin{array}{ll}
\mathrm{IC} & =\text { Income } \\
\% \mathrm{TC} & =\text { Percentage of income for travel cost } \\
\mathrm{D} & =\text { Travel frequency }
\end{array}
$$

The high-speed train services offer options that represent packages of different attributes. As described in previous section, the factor which influences transport mode choice behavior determined as attribute used in this study is travel time. The questionnaires explore how much the respondents want to pay with different travel times. The value of WTP obtained from each respondent is in the form of maximum value of money that is willing to be paid by the respondent for the tariff of high-speed train service. These values then processed to get the mean of WTP values, with the following formula.

$$
M W T P=\frac{1}{n} \sum_{i=1}^{n} W T P_{i}
$$

where:

MWTP $=$ Mean of WTP values

$\mathrm{n} \quad=$ Sample size

WTPi $=$ the maximum WTP value of the $\mathrm{i}$-th respondent

The respondents' WTP are shown in the form of comparison diagram (frequency and cumulative frequency percentage) towards ATP for each time travel scenario and also in the table illustrating the comparison of the average value against the average ATP to find out how much utility the high-speed train service is.

\section{Results AND ANALYsis}

\subsection{Review of Respondents Characteristic}


The aircraft passengers were asked by surveyors based on questions on the questionnaire and the answers were written on it. The number of questionnaires collected from SoekarnoHatta International Airport and Halim Perdanakusuma International Airport were 438 and 519, respectively, while 485 were collected from Juanda International Airport Surabaya, resulting in a total of 1442 forms collected. The questionnaire was designed to collect data on respondent profile such as age, gender, education level, job, income level, and travel purpose. Fig.4. below shows the result of respondent profile.

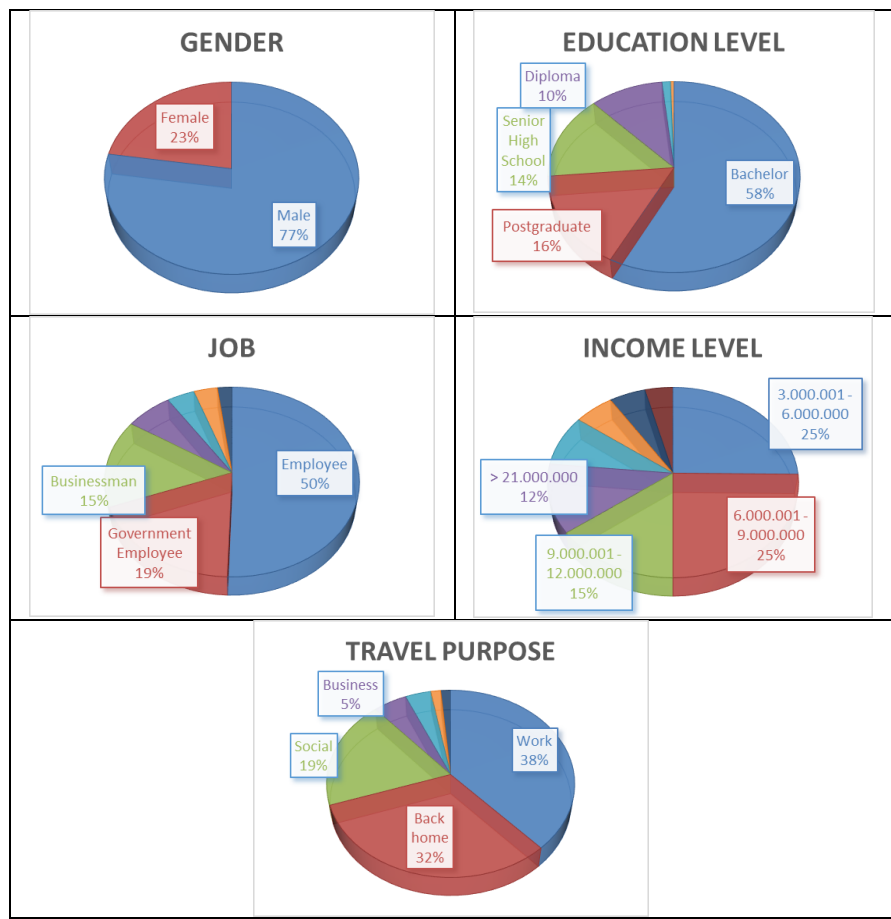

Fig.4. Respondent Profile

Based on Fig.4., respondents are predominantly male (77\%) and 58\% had undergraduate education background followed by postgraduate $(16 \%)$ as the second largest. This is also related to their occupation where half of the respondents are private employees, government employees (19\%), businessman $(15 \%)$, etc. This indicates that almost all respondents are active workers who have steady income.

Result survey shows the monthly earning of respondents are vary i.e. IDR 3.000 .000 - IDR $6.000 .000(25 \%)$, IDR 6.000 .000 - IDR 9.000.000 (25\%), IDR 9.000.000 - IDR $12.000 .000(15 \%)$, more than IDR $21.000 .000(12 \%)$ and the rest are in the range of IDR 12.000.000 - IDR 21.000.000. Majority of them use aircraft for working matters (38\%), returning home (32\%), doing social activity (19\%), doing business $(5 \%)$, etc. Because of aircraft mode is used for working matters, no matter how much the ticket price does not seem to be a problem. Yet because also many use for returning home, this means the aircraft is one of the favorite public transportation to consider as well.

\subsection{Analysis of ATP and WTP Measurement}

The other section of questionnaire was about exploring ATP and WTP of respondent. Error! Reference source not found. below shows the key questions for ATP and WTP measurement in this survey.

TABLE IV

ATP AND WTP MEASUREMENT

\begin{tabular}{|c|c|c|}
\hline \multicolumn{3}{|c|}{ Question Section } \\
\hline Characteristic & ATP & WTP \\
\hline $\begin{array}{ll}\text { - } & \text { Most used } \\
\text { transportation } \\
\text { mode } \\
\text { - } & \text { Alternative } \\
\text { transportation } \\
\text { mode } \\
\text { - } & \text { Ticket price } \\
\text { - } & \text { Travel time (on } \\
\text { board) }\end{array}$ & $\begin{array}{l}\text { \% of income } \\
\text { allocation for } \\
\text { monthly } \\
\text { transportation } \\
\text { costs } \\
\text { the ability of } \\
\text { one-way } \\
\text { transportation } \\
\text { cost } \\
\text { - Travel } \\
\text { frequency of } \\
\text { Jakarta- } \\
\text { Surabaya per } \\
\text { year }\end{array}$ & $\begin{array}{l}\text { Tariffs that are } \\
\text { willing to be paid } \\
\text { for scenario } 1,2 \\
\text { and } 3 \text { (see } \\
\text { TABLE II } \\
\text { VALUE OF EACH } \\
\text { ATTRIBUTE LEVEL } \\
\quad \text { ) }\end{array}$ \\
\hline
\end{tabular}

In Fig. 5. can be seen that respondent prefer aircraft rather than train for Jakarta-Surabaya trip that is as much $88 \%$ of total respondent, follows by train as second choice for only $9 \%$ of total respondent. At this point, aircraft is still being the favorite transportation for this route.

If the first choice of the most used transportation is not available due to some occasions like run out of ticket, high price, etc., the respondent will switch the most to the train that is $54 \%$ of total respondent and the second at $27 \%$ are choosing aircraft as seen in Fig. 6. This indicates an opportunity for high-speed train to compete with aircraft if it offers travel attributes that benefit passengers such as shortest travel time or lower price.

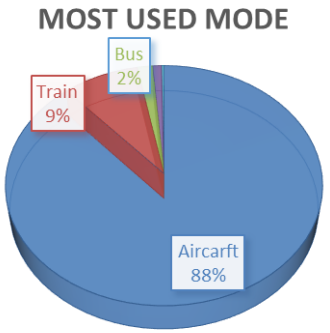

Fig. 5. The Most Used Transportation for Jakarta-Surabaya Trip

\section{ALTERNATIVE USED MODE}

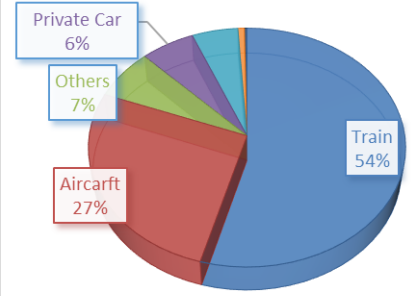


Fig. 6. The Alternative Used Transportation for Jakarta-Surabaya Trip

The ability to pay will be greatly influenced by the level of income. From the survey results, the average ticket price of Jakarta-Surabaya route paid by passengers is IDR 794.328. This will be the reference price for determining the range of high-speed train ticket price. The average ATP of respondent is IDR 810.580 , slightly higher than the average ticket price based on survey, means that respondents are able to pay for this trip at this rate. Based on this average, analysis of WTP will be approached upon the ticket price range desired by respondent.

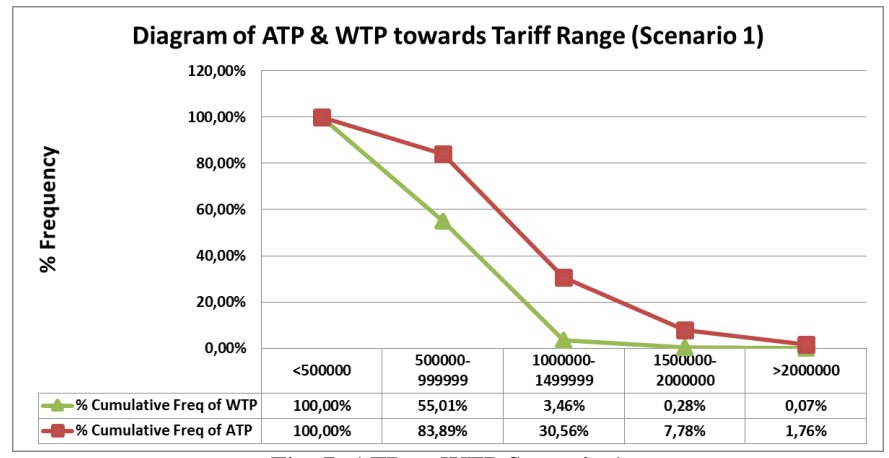

Fig. 7. ATP vs WTP Scenario 1

When respondent is offered with scenario 1 where the high-speed train operates for 4 hours, the ATP in the range of IDR 500.000 - IDR 1.000 .000 is reaching $83,89 \%$ of total respondent. In this range, the WTP value is still above $50 \%$ meaning that half of respondents are still willing to pay the price of high-speed train ticket at this range.

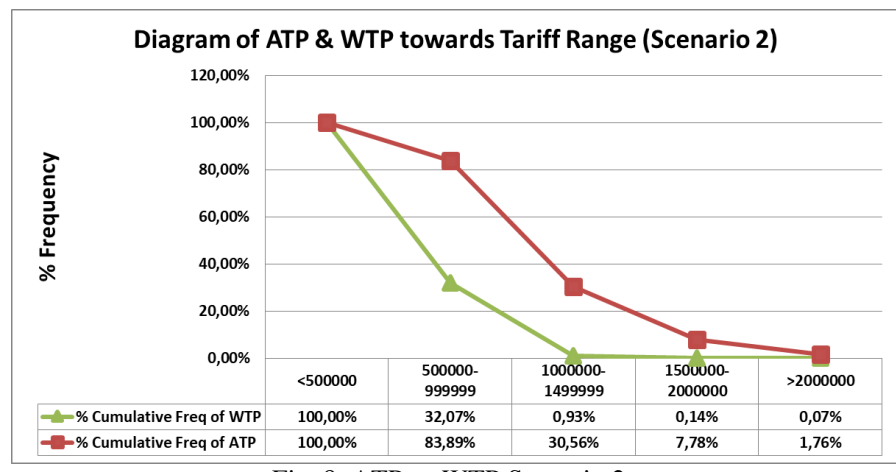

Fig. 8. ATP vs WTP Scenario 2

If the respondent is offered with scenario 2 where the high-speed train operates for 5 hours, then the WTP of respondent in the range of IDR 500.000 - IDR 1.000.000 is only $32,07 \%$. This value drops when compared to WTP in scenario 1 . This meaning that only one third of respondents are willing to pay the price of high-speed train ticket at this range.

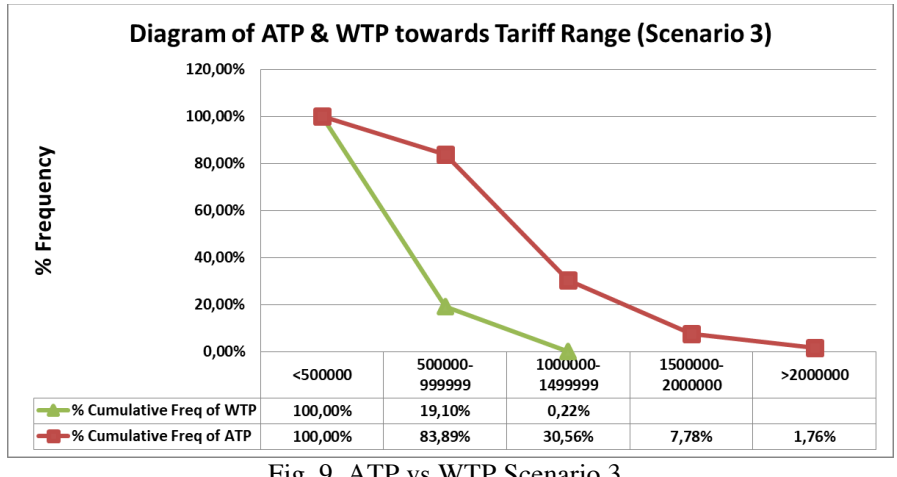

Fig. 9. ATP vs WTP Scenario 3

The last scenario, where the high-speed train operates for 6 hours, the WTP of respondent in the range of IDR 500.000 IDR 1.000 .000 is dramatically dropped into $19,10 \%$ meaning that only $19,10 \%$ respondents are willing to pay the price of high-speed train ticket at this range. This value is very low for aircraft passengers probability will switch to high-speed train.

Table V below shows the average of ATP and WTP for 3 scenarios offered to respondents. This average of WTP calculated by formula (2). In Scenario 1, average of WTP is around IDR 500.000, while for scenario 2 and 3, the average of ATP are around IDR 400.000 and IDR 300.000, respectively. This meaning that minimum tariff of high-speed train could be set on these average values, then called as a lower limit.

TABLE V

\begin{tabular}{cccc}
\multicolumn{4}{c}{ AVERAGE OF ATP AND WTP } \\
\hline ATP & & WTP (IDR) \\
(IDR) & Scenario 1 & Scenario 2 & Scenario 3 \\
\hline 810.580 & 498.701 & 414.426 & 331.350 \\
\hline
\end{tabular}

\section{CONCLUSIONS}

All scenarios show that WTP is always less than ATP meaning that utility to high-speed train services is relatively low but passengers' income is relatively high. Decrease in WTP value in each scenario is directly affected by travel time attribute. The longer the high-speed train operation time the smaller WTP of respondent.

From the survey results in the average ticket price paid by the respondent, the cumulative frequency probability ratio of ATP-WTP and the average ATP-WTP, it can be proposed the minimum tariff rate for high-speed train.

TABLE VI

RANGE OF FEASIBLE TARIFF OF HIGH- SPEED TRAIN

\begin{tabular}{ccc}
\hline \multicolumn{3}{c}{ Range of Feasible Tariff (IDR) } \\
Scenario 1 & Scenario 2 & Scenario 3 \\
\hline $500.000-600.000$ & $400.000-500.000$ & $300.000-400.000$ \\
\hline
\end{tabular}

This proposed tariff is still within the limits of ability to pay and entered in the range of willingness to pay of aircraft passengers and also still lower than average ticket price paid by the aircraft passengers. However, in order to gain a lot of aircraft passengers who want to switch to high-speed train, scenario 1 (travel time - 4 hours) is the most feasible option to be applied with range of tariff IDR 500.000- IDR 600.000. As we know, the travel time between Jakarta and Surabaya by 
using aircraft is about 3,5 hours or more while using the fastest existing train, Argo Bromo Anggrek, is about 9 hours. It means scenario 1 travel time is still compete with aircraft and much lower than fastest existing train. By applied this scenario, it can be expected that half of aircraft passengers are willing to switching their mode into high-speed train and pay the price of high-speed train ticket at this range. However, this study had certain limitations in analyzing passengers preferences due to its analyzed travel attribute was only travel time. In advanced studies, other travel attributes that are considered to have a major effect on the behavior of the election mode need to be expanded.

\section{REFERENCES}

[1] H.D. Cho, "The Factors that Affect Long-Distance Travel Mode Choice Decisions and Their Implications for Transportation Policy," Dissertation of the University of Florida, 2013.

[2] Sperry, B.R., Burris, M. and Woosnam, K.M., "Investigating the impact of high-speed rail equipment visualization on mode choice models: Case study in central Texas," Case Studies on Transport Policy, 5, 560-572, 2017.

[3] J.K. Shadewald, S. Hallmark, and R. Souleyrette, "Visualizing System Wide Economic Impacts of Transportation Projects," Urban Planning and Development 127 (4), 158-168, December, 2001.

[4] T. Anas, and F. Christopher, "Indonesia: Structural Reform in Air Transport Service," APEC Economic Policy Report 2016, APEC Policy Support Unit, Singapore, 2016.

[5] GAPEKA, "Train Travel Diagram Sheets. Decree of the Director General of Railways," Indonesia Ministry of Transportation, 2017.

[6] R.A. Musgrave, and P.B. Musgrave, "Public Finance in Theory and Practice," McGraw-Hill, New York, 1975.

[7] Y. Al-Ghuraiz, and A. Enshassi, "Ability and Willingness to Pay for Water Supply Service in the Gaza Strip," Building and Environment 40, 1093-1102, 2005.

[8] D.N. Wulansari, O.Z. Tamin, S.S. Wibowo and W. Weningtyas, "Analisis Ability to Pay (ATP) dan Willingness to Pay (WTP) Pengguna Kereta Api Bandara," Master Thesis, Civil Engineering Department, Bandung Institute of Technology, Bandung, 2015.

[9] J.J. Louviere, D.A. Hensher, and J. Swait, "Stated Choice Methods: Analysis and Application," Cambridge University Press, Cambridge, 2000.

[10] Breidert, C., Hahsler, M. and Reutterer, T., "A review of methods for measuring willingness-to-pay," Innovative Marketing, 2(4), pp.8-32, 2006.

[11] Ability to Pay (ATP)/ Willingness to Pay (WTP), http://dardela.com/index.php?option $=$ com_content\&task $=$ view\&id $=87 \&$ Itemid=46, 2009 .

[12] IATA Air Transport Consultancy Services, "Air/Rail Inter-Modality Study," Final Report, 2003.

[13] Y. Park, and H. K. Ha, "Analysis of the Impact of High-Speed Railroad Service on Air Transport Demand,” Transp. Res. Part E 42 (2), 2006.

[14] S. Suh, Y. Keun-yul, and K. Jeon Hyun, "Effects of Korean Train Express (KTX) Operation on the National Transport System," Proc. Eastern Asia Soc. Transp. Stud. 5, 175-189, 2005.

[15] Y.H. Cheng, "High-speed rail in Taiwan: New experience and issues for future development," Transport Policy 17, 51-63, 2010.

[16] C. Behrens, and E. Pels, "Intermodal Competition in the London-Paris Passenger Market: High-Speed Rail and Air Transport," J. Urban Econ. 71 (3), 278-288, 2012.
[17] L. Arsyad, and Soeratno, "Metodologi Penelitian Untuk Ekonomi dan Bisnis,” UPPAMP YKPN, Yogyakarta, 1995. 